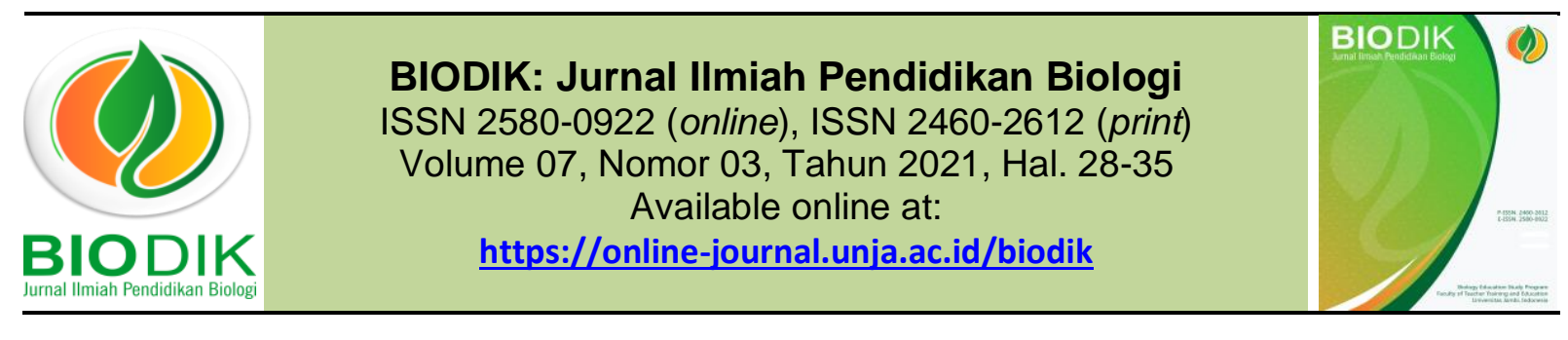

Research Article

OPEN ACCESS

\title{
Pengembangan E-LKPD Berbasis Saintifik Materi Sistem Pernapasan pada Manusia Kelas XI SMA
}

\section{(Development of E-LKPD Based on Scientific in Human Respiratory System for Senior High School Students Grade XI)}

\author{
Winda Amthari, Damris Muhammad, Evita Anggereini \\ Universitas Jambi \\ Jl. Lintas Jambi-Ma.Bulian KM 15 Mendalo Indah-Jambi-Indonesia \\ *Corresponding Author: amthariwinda@gmail.com
}

\begin{tabular}{|c|c|}
\hline Informasi Artikel & ABSTRACT \\
\hline $\begin{array}{l}\text { Submit: } 11-06-2021 \\
\text { Diterima: } 15-08-2021 \\
\text { Dipublikasikan: } 14-09-2021\end{array}$ & $\begin{array}{l}\text { Student worksheet (LKPD) is a teaching material which can be developed by a } \\
\text { teacher to be used in learning process. Based on the observation result in SMAN } \\
2 \text { Kota Jambi, most of the students are still struggling in understanding the } \\
\text { human respiratory system material. Electronic LKPD or e-LKPD contains } \\
\text { learning material with images and videos which make students learn easier. } \\
\text { Teaching material such as e-LKPD can be integrated with scientific approach } \\
\text { which stimulates students' involvement in learning process. This research aims } \\
\text { to develop scientific based e-LKPD for human respiratory system material for } \\
\text { Senior High School grade XI, to find out about the properness, teachers' and } \\
\text { students' response, and the effectiveness of e-LKPD in improving learning } \\
\text { outcomes. The development of e-LKPD used ADDIE model which consists of } \\
\text { analysis, design, development, implementation, and evaluation. The e-LKPD } \\
\text { product has been validated by the media and material experts with very good } \\
\text { result. The result of biology teacher's response and the result of students' trial } \\
\text { on small and big group showed very good result. The result of effectiveness test } \\
\text { using paired sample t test showed that there is an effect of using scientific based } \\
\text { e-LKPD on human respiratory system material in improving student learning's } \\
\text { outcomes. Thus, scientific based e-LKPD for human respiratory system material } \\
\text { is an appropriate teaching material and can improve students' learning } \\
\text { outcomes. } \\
\text { Key words: E-LKPD, human respiratory system, scientific }\end{array}$ \\
\hline Penerbit & ABSTRAK \\
\hline $\begin{array}{l}\text { Program Studi Pendidikan Biologi } \\
\text { FKIP Universitas Jambi, } \\
\text { Jambi- Indonesia }\end{array}$ & $\begin{array}{l}\text { Lembar Kerja Peserta Didik (LKPD) merupakan bahan ajar yang dapat } \\
\text { dikembangkan oleh guru untuk digunakan dalam pembelajaran. Berdasarkan } \\
\text { observasi di SMAN } 2 \text { Kota Jambi, sebagian besar peserta didik mengalami } \\
\text { kesulitan dalam memahami materi sistem pernapasan manusia. LKPD } \\
\text { elektronik atau e-LKPD memuat materi pembelajaran yang dilengkapi dengan } \\
\text { gambar serta video yang memudahkan dalam memahami materi tersebut. } \\
\text { Bahan ajar seperti e-LKPD dapat diintegrasikan dengan pendekatan saintifik } \\
\text { yang merangsang keterlibatan peserta didik dalam proses pembelajaran. } \\
\text { Penelitian ini bertujuan untuk mengembangkan e-LKPD berbasis saintifik materi } \\
\text { sistem pernapasan pada manusia kelas XI SMA, mengetahui kelayakan, respon } \\
\text { guru dan peserta didik, serta efektivitas e-LKPD yang dikembangkan dalam } \\
\text { meningkatkan hasil belajar. Pengembangan e-LKPD menggunakan model } \\
\text { ADDIE yang terdiri dari tahap analysis, design, development, implementation } \\
\text { dan evaluation. Produk e-LKPD divalidasi oleh ahlimedia dan ahli materi dengan } \\
\text { perolehan hasil sangat baik. Hasil respon guru biologi serta ujicoba kelompok } \\
\text { kecil dan kelompok besar diperoleh hasil sangat baik. Hasil uji efektivitas } \\
\text { menggunakan uji paired sample } t \text { test menunjukkan terdapat pengaruh }\end{array}$ \\
\hline
\end{tabular}



dalam meningkatkan hasil belajar. Dengan demikian e-LKPD berbasis saintifik materi sistem pernapasan pada manusia yang dikembangkan layak digunakan sebagai bahan ajar dan dapat meningkatkan hasil belajar peserta didik.

Kata kunci: E-LKPD, saintifik, sistem pernapasan manusia

\section{(i)(2)}

BY NC SA

This BIODIK : Jurnal IImiah Pendidikan Biologi is licensed under a CC BY-NC-SA (Creative Commons Attribution-ShareAlike 4.0 International License)

\section{PENDAHULUAN}

Pembelajaran memegang peranan penting dalam tercapainya tujuan pendidikan. Dalam proses pembelajaran, peserta didik diarahkan agar berperan aktif untuk membangun pengetahuannya sehingga pembelajaran menjadi lebih bermakna. Bahan ajar menjadi salah satu faktor yang dapat menunjang keberhasilan proses pembelajaran. Guru sebagai pendidik berperan untuk menyediakan bahan ajar yang membantu peserta didik dalam mencapai tujuan pembelajaran. Bahan ajar merupakan salah satu sarana yang dapat menunjang proses pembelajaran. Abidin (2016) menjelaskan bahwa bahan ajar dapat diartikan sebagai seperangkat fakta, konsep, prinsip, prosedur, dan atau generalisasi yang dirancang secara khusus untuk memudahkan suatu pengajaran. Daryanto dan Dwicahyono (2014) juga menambahkan bahwa bahan ajar merupakan bahan atau materi pembelajaran yang disusun secara sistematis yang digunakan guru dan peserta didik dalam kegiatan belajar. Bahan ajar yang disusun secara sistematis dan menarik dapat memotivasi serta mendukung pemahaman peserta didik terhadap suatu materi pembelajaran.

Lembar Kerja Peserta Didik (LKPD) merupakan salah satu bahan ajar yang dapat dikembangkan oleh guru untuk digunakan dalam proses pembelajaran. Prastowo (2011) menjelaskan bahwa LKPD merupakan bahan ajar yang sudah dikemas sedemikian rupa, sehingga peserta didik diharapkan dapat mempelajari materi ajar tersebut secara mandiri. Majid (2015) juga menambahkan bahwa LKPD dalam kegiatan belajar mengajar dapat dimanfaatkan pada tahap penanaman konsep (menanamkan konsep baru) atau pemahaman konsep karena LKPD dirancang untuk membimbing peserta didik dalam mempelajari topik. Dengan demikian LKPD diharapkan dapat mengoptimalkan proses pembelajaran. Perkembangan teknologi yang semakin dinamis telah banyak membawa perubahan dan kemajuan pada bidang pendidikan. Sebagai pendidik sudah seharusnya kita mempertimbangkan dan mengikuti kemajuan teknologi tersebut. Guru sebagai pendidik dapat menyediakan bahan ajar yang menarik seperti LKPD dengan menggunakan perangkat elektronik. LKPD elektronik atau yang disingkat dengan e-LKPD dapat memuat materi pembelajaran yang dilengkapi dengan gambar, dan video yang dapat menarik perhatian peserta didik dalam belajar dan membantu peserta didik dalam memahami materi tersebut.

Bahan ajar seperti e-LKPD dapat diintegrasikan dengan menggunakan pendekatan saintifik yang dapat merangsang keterlibatan peserta didik dalam proses pembelajaran. Pendekatan saintifik merupakan pendekatan pembelajaran yang memberikan kesempatan kepada peserta didik untuk mendapatkan pengalaman belajar melalui mengamati, menanya, mengumpulkan informasi, mengasosiasi dan mengkomunikasikan (Daryanto dan Karim, 2017). Selanjutnya Saefudin dan Berdiati (2016) juga menjelaskan bahwa pembelajaran saintifik tidak hanya memandang hasil belajar sebagai muara akhir, namun proses pembelajaran dipandang sangat penting. Oleh karena itu, pembelajaran saintifik menekankan pada keterampilan proses. 
Berdasarkan hasil observasi yang telah dilakukan di SMAN 2 Kota Jambi melalui wawancara dengan guru biologi, didapatkan informasi bahwa kurikulum yang digunakan oleh sekolah adalah kurikulum 2013. Pembelajaran biologi di sekolah tersebut juga telah berlangsung dengan baik, guru juga telah menggunakan bahan ajar berupa buku paket dan LKPD cetak. Namun, sebagian besar peserta didik masih mengalami kesulitan dalam memahami materi sistem pernapasan pada manusia yang dipelajari di kelas XI SMA. Peserta didik membutuhkan bahan ajar baru yang dapat mendukung pemahaman peserta didik terhadap materi sistem pernapasan pada manusia. Melihat permasalahan tersebut, maka diperlukan adanya pengembangan bahan ajar yang dapat mendukung proses pembelajaran pada materi sistem pernapasan. Bahan ajar seperti e-LKPD yang dirancang secara menarik diharapkan dapat membantu peserta didik dalam memahami materi sistem pernapasan tersebut. Selain itu, Bahan ajar seperti e-LKPD yang dibuat dengan pendekatan saintifik juga diharapkan dapat mendorong peserta didik untuk aktif dalam kegiatan pembelajaran, sehingga membuat proses pembelajaran menjadi lebih bermakna. Tujuan dari penelitian ini adalah untuk untuk mengembangkan eLKPD berbasis saintifik materi sistem pernapasan pada manusia kelas XI SMA, mengetahui kelayakan, respon guru dan peserta didik serta efektivitas e-LKPD yang dikembangkan dalam meningkatkan hasil belajar peserta didik.

\section{METODE PENELITIAN}

Penelitian ini tergolong penelitian pengembangan (Research and Development). Penelitian pengembangan merupakan metode penelitian yang digunakan untuk menghasilkan produk tertentu dan menguji keefektifan produk tersebut (Sugiyono, 2013). Model pengembangan yang digunakan untuk mengembangkan e-LKPD berbasis pendekatan saintifik pada materi sistem pernapasan manusia adalah model pengembangan ADDIE. Model pengembangan ADDIE terdiri dari 5 tahapan yaitu tahap analysis (analisis), design (desain), development (pengembangan), implementation (implementasi), dan evaluation (evaluasi).

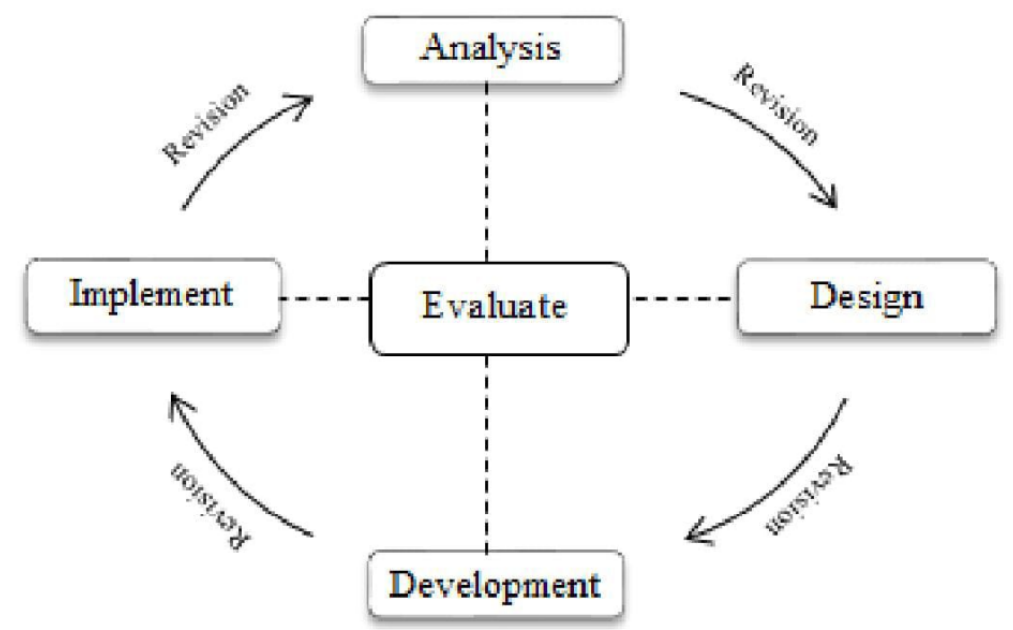

Gambar 1. Langkah-langkah model pengembangan ADDIE (Branch, 2009)

\section{Tahap Analisis}

Analisis kebutuhan pengembangan produk merupakan hal penting dilakukan untuk memastikan bahwa produk yang akan dikembangkan sesuai dengan kebutuhan pengguna (Rusdi, 2019). Tahap 
analisis terdiri dari analisis kebutuhan, analisis karakteristik peserta didik, dan analisis kurikulum. Analisis kebutuhan dilakukan melalui wawancara dengan guru biologi serta analisis kebutuhan peserta didik melalui pengisian angket oleh peserta didik. Analisis karakteristik peserta didik dilakukan dengan mewawancarai Waka Kesiswaan di sekolah untuk melihat keadaan peserta didik agar menunjang keberhasilan pengembangan dan sesuai dengan keadaan pengguna. Analisis kurikulum dilakukan dengan tujuan untuk menetapkan kompetensi dari bahan ajar yang akan dikembangkan.

\section{Tahap Desain}

Tahap desain terdiri dari menentukan tim pengembang, menyusun jadwal pengembangan dan pengumpulan bahan-bahan yang dimasukkan seperti uraian materi, gambar, video, soal serta langkah kegiatan pembelajaran, serta membuat flowchart dan storyboard sebagai rancangan produk awal yang bertujuan untuk mempermudah peneliti dalam mengembangkan e-LKPD berbasis saintifik materi sistem pernapasan pada manusia.

\section{Tahap Pengembangan}

Tahap pengembangan dilakukan dengan merealisasikan e-LKPD berbasis saintifik pada materi sistem pernapasan pada manusia yang sudah dirancang untuk dikembangkan. Selanjutnya dilakukan validasi pada produk yang dikembangkan tersebut. Validasi dilakukan oleh ahli materi dan ahli media. Suryani, $d k k$ (2018) menjelaskan bahwa ahli media berperan dalam memberi saran dan kritik terhadap media yang telah dikembangkan. Setelah mendapatkan hasil validasi, kemudian dilakukan perbaikan terhadap e-LKPD yang dikembangkan. Perbaikan atau revisi ini dilakukan hingga produk bahan ajar berupa e-LKPD berbasis saintifik pada materi sistem pernapasan manusia dinyatakan layak oleh ahli materi dan ahli media untuk diimplementasikan.

\section{Tahap Implementasi}

Tahapan implementasi merupakan tahapan penerapan produk e-LKPD berbasis saintifik pada materi sistem pernapasan yang telah dinyatakan layak oleh tim ahli. Produk tersebut diujicobakan pada 2 orang guru biologi, serta ujicoba pada peserta didik yang terdiri dari ujicoba kelompok kecil berjumlah 6 orang peserta didik dan ujicoba kelompok besar berjumlah 16 orang peserta didik untuk mendapatkan data guna mengetahui kelayakan penggunaan produk tersebut serta respon terhadap produk berdasarkan angket yang akan diisi oleh guru dan peserta didik sebagai subjek ujicoba. Selanjutnya dilakukan uji efektivitas terhadap 15 orang peserta didik untuk melihat pengaruh produk yang dikembangkan terhadap hasil belajar.

\section{Tahap Evaluasi}

Tahap evaluasi dilakukan untuk melihat dan mengukur ketercapaian bahan ajar berupa e-LKPD berbasis saintifik pada materi sistem pernapasan yang telah dikembangkan. Pada penelitian ini, evaluasi dilakukan dengan dua tahap yaitu evaluasi formatif dan evaluasi sumatif. Pada evaluasi formatif, hasil penilaian dan saran yang diberikan tim ahli dijadikan sebagai bahan pertimbangan dalam melakukan evaluasi formatif. Pada evaluasi sumatif, hasil penilaian dari peserta didik terhadap produk yang digunakan, dijadikan sebagai bahan dalam melaksanakan evaluasi sumatif. Hasil dari evaluasi ini bertujuan untuk mengetahui apakah e-LKPD berbasis saintifik yang telah dikembangkan layak dapat digunakan dalam pembelajaran pada materi sistem pernapasan manusia. 


\section{HASIL PENELITIAN DAN PEMBAHASAN}

Hasil pengembangan produk dinilai oleh validator ahli materi dan validator ahli media untuk menilai kelayakannya. Saran dan komentar dari validator dijadikan sebagai bahan untuk melakukan revisi dan perbaikan terhadap e-LKPD berbasis saintifik materi sistem pernapasan pada manusia yang dikembangkan. Adapun tahapan validasi adalah sebagai berikut:

a. Validasi Materi

Proses validasi oleh ahli materi dilakukan sebanyak dua kali. Berikut adalah grafik penilaian e-LKPD oleh ahli materi.

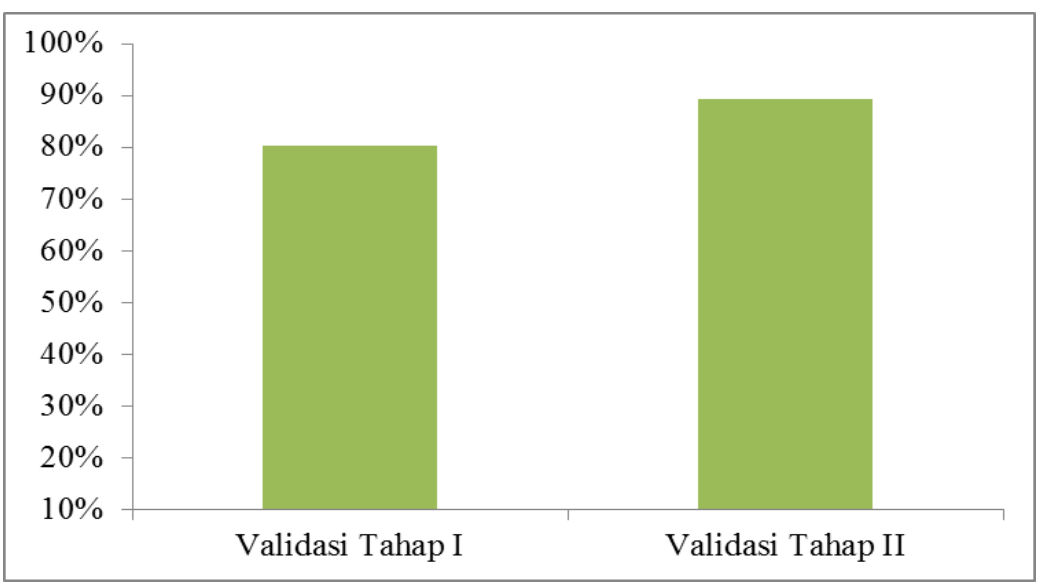

Gambar 2. Penilaian e-LKPD oleh ahli materi

Berdasarkan gambar 2 terlihat bahwa hasil persentase validasi oleh ahli materi menunjukkan bahwa terjadi peningkatan skor dari validasi pertama dan validasi kedua. Pada tahap validasi pertama diperoleh skor 45 dengan persentase $80,36 \%$ dengan kategori baik. Pada validasi tersebut terdapat beberapa saran dari validator yang perlu diperbaiki oleh penulis. Setelah diperbaiki, pada validasi kedua terjadi peningkatan skor menjadi 50 dengan persentase sebesar 89,29\% kategori sangat baik. Hal ini menunjukkan bahwa e-LKPD berbasis saintifik materi sistem pernapasan pada manusia layak diujicobakan tanpa revisi.

b. Validasi Media

Validasi oleh ahli media dilakukan sebanyak dua kali. Berikut adalah grafik penilaian e-LKPD oleh ahli media.

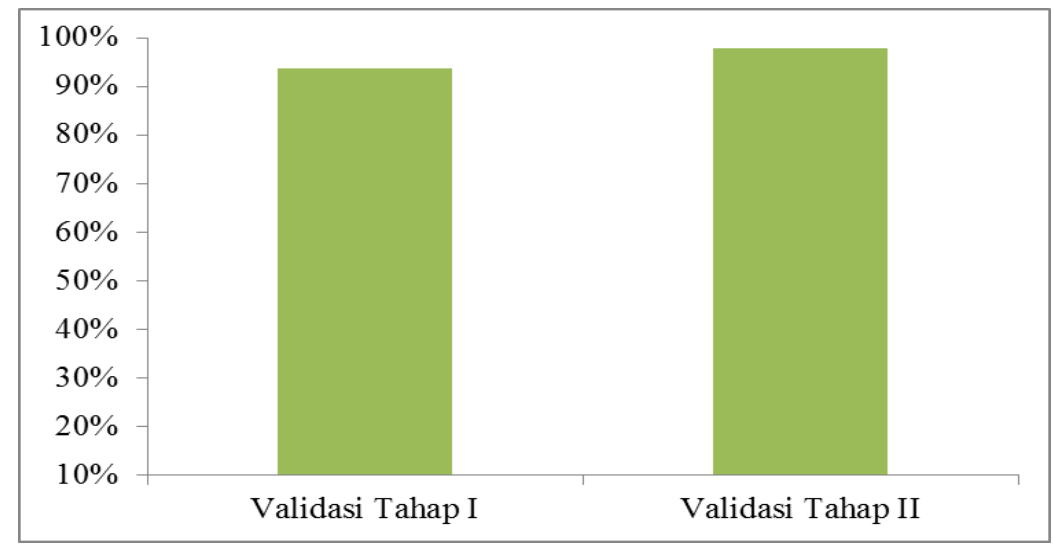

Gambar 3. Penilaian e-LKPD oleh ahli media 
Berdasarkan gambar 3 hasil persentase validasi oleh ahli media menunjukkan bahwa terjadi peningkatan skor dari validasi pertama dan validasi kedua. Pada tahap validasi pertama diperoleh skor 45 dengan persentase $93,75 \%$ termasuk kategori sangat baik. Namun, pada validasi tersebut terdapat beberapa saran dari validator yang perlu diperbaiki oleh penulis. Setelah diperbaiki, pada validasi kedua terjadi peningkatan skor menjadi 47 dengan persentase sebesar 97,92\% termasuk dalam kategori sangat baik. Produk e-LKPD berbasis saintifik yang dikembangkan dinyatakan layak diujicobakan tanpa revisi.

Setelah e-LKPD berbasis saintifik materi sistem pernapasan pada manusia dinyatakan layak oleh ahli, maka dilakukan tahapan ujicoba untuk melihat respon guru dan peserta didik. Ujicoba produk pada guru dilakukan untuk melihat respon guru terhadap e-LKPD berbasis saintifik materi sistem pernapasan pada manusia yang dikembangkan. Pengambilan data dilakukan melalui 2 orang guru biologi dengan menggunakan angket. Pada hasil ujicoba produk pada 2 orang guru tersebut diperoleh jumlah skor sebesar 78 dengan persentase sebesar $97,5 \%$ dan termasuk ke dalam kategori sangat baik. Hal ini menunjukkan bahwa e-LKPD berbasis saintifik materi sistem pernapasan pada manusia layak digunakan sebagai bahan ajar dalam pembelajaran biologi materi sistem pernapasan pada manusia untuk kelas XI SMA.

Ujicoba kelompok kecil dilakukan terhadap 6 orang peserta didik. Ujicoba tersebut bertujuan untuk melihat respon peserta didik terhadap e-LKPD berbasis saintifik materi sistem pernapasan pada manusia yang dikembangkan. Dari hasil ujicoba kelompok kecil diperoleh skor sebesar 225, apabila dipersentasekan sebesar $93,75 \%$ dengan kategori sangat baik. Produk e-LKPD berbasis saintifik materi sistem pernapasan pada manusia yang telah dinyatakan layak untuk digunakan dalam proses pembelajaran, selanjutnya diimplementasikan pada kelompok besar berjumlah 16 orang peserta didik. Hasil ujicoba kelompok besar menunjukkan bahwa e-LKPD berbasis saintifik materi sistem pernapasan pada manusia sangat layak digunakan di dalam proses pembelajaran dengan perolehan skor sebesar 599, apabila dipersentasekan sebesar 93,59\% dengan kategori sangat baik.

Menurut Sriwahyuni $d k k,(2019)$ bahan ajar ektronik adalah bahan ajar yang isi materinya dimuat dalam bentuk elektronik yaitu bisa berupa audio, audio visual, ataupun berupa multimedia interaktif. Selanjutnya, bahan ajar juga diintegrasikan menggunakan pendekatan saintifik. Rusman (2017) menjelaskan bahwa pendekatan saintifik merupakan pendekatan dalam pembelajaran yang memberikan kesempatan kepada peserta didik secara luas untuk melakukan eksplorasi dan elaborasi materi yang dipelajari, disamping itu memberikan kesempatan kepada peserta didik untuk mengaktualisasikan kemampuaanya melalui kegiatan pembelajaran yang telah dirancang oleh guru. Hal ini tentu saja membuat proses pembelajaran menjadi lebih menarik dan membantu peserta didik memahami materi yang terdapat di dalam e-LKPD tersebut.

Analisis uji efektivitas penggunaan e-LKPD berbasis saintifik materi sistem pernapasan pada manusia dilakukan dengan membandingkan nilai pretest dan posttest. Hasil analisis uji efektivitas melalui uji t berpasangan (t-test paired) dapat dilihat pada tabel 1 .

Tabel 1. Uji paired sample t-test hasil belajar

Paired Samples Test

\begin{tabular}{|c|c|c|c|c|c|c|c|c|}
\hline & \multicolumn{5}{|c|}{ Paired Differences } & \multirow[b]{3}{*}{$t$} & \multirow[b]{3}{*}{$\mathrm{df}$} & \multirow[b]{3}{*}{ Sig. (2-tailed } \\
\hline & \multirow[b]{2}{*}{ Mean } & \multirow[b]{2}{*}{ Std. Deviation } & \multirow{2}{*}{$\begin{array}{l}\text { Std. Error } \\
\text { Mean }\end{array}$} & \multicolumn{2}{|c|}{$\begin{array}{l}\text { 95\% Confidence Interval of the } \\
\text { Difference }\end{array}$} & & & \\
\hline & & & & Lower & Upper & & & \\
\hline Pair 1 Pretest-Posttest & $-12,33333$ & 3,71612 & 95950 & $-14,39125$ & $-10,27542$ & $-12,854$ & 14 &, 000 \\
\hline
\end{tabular}


Pada tabel 1 terlihat bahwa nilai Sig. (2-tailed) yang diperoleh sebesar 0,000 (kecil dari 0,05), maka $\mathrm{H}_{0}$ ditolak dan $\mathrm{H}_{1}$ diterima. Sehingga dapat disimpulkan bahwa ada perbedaan rata-rata antara hasil belajar pretest dengan posttest, artinya ada pengaruh penggunaan e-LKPD berbasis saintifik materi sistem pernapasan pada manusia dalam meningkatkan hasil belajar.

Produk e-LKPD memuat materi pembelajaran yang dilengkapi dengan gambar, dan video yang dapat menarik perhatian peserta didik dalam belajar dan mendukung pemahaman peserta didik pada materi tersebut. Bahan ajar seperti e-LKPD yang diintegrasikan dengan pendekatan saintifik yang dapat merangsang keterlibatan peserta didik dalam proses pembelajaran. Saefudin dan Berdiati (2016) menjelaskan bahwa pendekatan saintifik merupakan konsep dasar yang mewadahi, menginspirasi, dan melatari pemikiran tentang bagaimana metode pembelajaran dapat diterapkan dalam teori tertentu. Melalui e-LKPD berbasis saintifik materi sistem pernapasan pada manusia yang telah dikembangkan dapat memberikan kesempatan pada peserta didik untuk menemukan atau membangun pengetahuan mereka sendiri.

\section{SIMPULAN}

Produk e-LKPD berbasis saintifik materi sistem pernapasan pada manusia dikembangkan menggunakan model pengembangan ADDIE yang terdiri dari 5 tahap yaitu analisis (analysis), desain (design), pengembangan (development), implementasi (implementation), dan evaluasi (evaluation). Hasil validasi oleh ahli materi diperoleh persentase $89,29 \%$ dengan kategori sangat baik dan hasil validasi oleh ahli media diperoleh persentase $97,92 \%$ dengan kategori sangat baik. Hasil respon guru biologi diperoleh persentase $97,5 \%$ dengan kategori sangat baik, hasil ujicoba untuk melihat respon peserta didik pada ujicoba kelompok kecil diperoleh persentase $93,75 \%$ dengan kategori sangat baik, dan ujicoba pada kelompok besar diperoleh persentase $93,59 \%$ dengan kategori sangat baik. Hasil uji efektivitas menggunakan uji paired sample $t$ test menunjukkan terdapat pengaruh penggunaan e-LKPD berbasis saintifik materi sistem pernapasan pada manusia dalam meningkatkan hasil belajar peserta didik.

\section{RUJUKAN}

Abidin, Y. (2016). Desain Sistem Pembelajaran Dalam Konteks Kurikulum 2013. Bandung: PT Refika Aditama

Branch, R.M. (2009). Instructional Design: The ADDIE Approach. New York: Springer

Daryanto dan Karim, S. (2017). Pembelajaran Abad 21. Yogyakarta: Gava Media

Daryanto dan Dwicahyono, A. (2014). Pengembangan Perangkat Pembelajaran (Silabus, RPP, PHB, Bahan Ajar). Yogyakarta: Gava Media

Majid, A. (2015). Strategi Pembelajaran. Bandung: PT. Remaja Rosdakarya

Prastowo, A. (2011). Panduan Kreatif Membuat Bahan Ajar Inovatif. Yogyakarta: Diva Press

Rusman. (2017). Belajar dan Pembelajaran Berorientasi Standar Proses Pendidikan. Jakarta: Kencana

Rusdi, M. (2019). Penelitian Desain dan Pengembangan Kependidikan. Depok: PT Raja Grafindo Persada

Saefudin, A. dan Berdiati, K. (2016). Pembelajaran Efektif. Bandung: PT. Remaja Rosdakarya 
BIODIK: Jurnal IImiah Pendidikan Biologi

Vol. 07, No. 03 (2021), Hal. $28-35$

Sriwahyuni, I., Risdianto, E., \& Johan, H. (2019). Pengembangan bahan ajar elektronik menggunakan flip PDF professional pada materi alat-alat optik di SMA. Jurnal Kumparan Fisika, 2(3), 145-152.

Sugiyono. (2013). Metode Penelitian Kuantitatif Kualitatif dan R\&D. Bandung: Alfabeta

Suryani, N., Setiawan, A.,\& Putria, A. (2018). Media Pembelajaran Inovatif dan Pengembangannya. Bandung: PT. Remaja Rosdakarya 